\section{Donker spoor.}

Martin Steyn. Pretoria: Lapa, 2014. 384 pp. ISBN 978-0-7993-6965-6 (gedrukte boek). ISBN 978-0-7993-6967-0 (ePub). ISBN 9780-7993-6969-4 (mobi).

DOI: http://dx.doi.org/10.4314/tvl.v53i1.26

"Dis altyd asof daar 'n lig in 'n ouer uitgedoof word wanneer ' $n$ kind vermoor word," lui die openingsparagraaf op die agterblad, 'n aanhaling uit Donker spoor, Martin Steyn se debuutroman.

'n Sensitiewe leser sal nie ywerig wees om hierdie boek te lees na aanleiding van die teks op die agterblad nie; 'n krimmieleser sal weer nie kan wag om die boek oop te slaan nie. Eersgenoemde mag dalk bang wees dat sy uit die slaap gehou sal word-en nie om dowe neute nie. 'n Reeksmoordenaar wat tienermeisies ontvoer, martel en verkrag, klink nie na ideale ontspanningslektuur nie.

Dit is egter presies wat Donker spoor doen: dit laat jou ontspan omdat jy totaal in die fiktiewe wêreld van die boek opgeneem word en jy van jou eie werklikheid vergeet. Én dit hou jou uit die slaap [...] omdat jy wil sien hoe adjudant-offisier Jan Magson (Mags) die monster vastrek. Wie is die moordenaar? Hoekom openbaar hy sulke dierlike gedrag?

Deur die roman word die grafiese tonele met sorg beskryf, amper onseremonieel, soos wat dit deel is van die daaglikse roetine van die patoloog en dikwels dié van die speurder. Die saaklike beskrywing van 'n postmortem deur dokter Killian, die patoloog, toon Steyn se noukeurige en omvattende navorsing wat breedvoerig aan die einde van die roman in 'n "skrywersnota" aan die leser beskryf word. Deur die loop van die boek word die leser van grusame inligting voorsien, sonder dat dit tot die sensasionele vereng word. 'n Lewensgetroue beeld word geskep van wat agter die skerms van 'n (moord)toneel gebeurvanuit die oogpunt van die moordenaar én die ondersoekbeamptes. Ons leer die moordenaar ken vanuit veral gesprekke tussen die tweemanskap-Mags en sy vennoot, Menck-waarin hulle motiewe, modus operandi en moontlike skuldiges oorweeg deur op hulle "kriminele brein" (27) staat te maak.

Daar word nie veel ruimte vir twyfel gelaat of Mags wel die moordenaar gaan vastrek nie; dit gaan veel eerder oor hoe en wanneer hy die moordenaar gaan uitoorlê. Tyd is van kardinale belang: hoe vinniger die moordenaar gevang word, hoe minder moorde sal gepleeg word, want moordenaars soos dié "sal nie vanself ophou nie" (72).

Soos in die klassieke speurverhaal, gebruik Steyn die tydfaktor om spanning te verhoog: meisies word ontvoer, maar hul lyke is nog nie gevind nie-wat beteken dat hulle dálk nog leef. Steyn neem die leser op die reeksmoordenaar se spoor,' $n$ tog om uit te vind of nóg lyke gevind gaan word en of die ontvoerde slagoffers betyds gered sal word. Gaan die moordenaar wraak neem op'n slagoffer wat naelskraap uit sy kloue ontsnap het? Hy het haar kontakbesonderhede. Intussen begin daar vreemde briewe by een van die slagoffers se huis opdaag...

Mags se persoonlike lewe meng uit die staanspoor met sy professionele lewe in. Sy gebrek aan slaap, die trauma van sy vrou se dood en die vervreemding van sy seun 
eis sy tol—dit bereik selfs ' $n$ punt waar hy deur sy bevelvoerder verplig word om vir professionele hulp te gaan. Voeg die druk van die media by, en dit wil voorkom asof Mags heel moontlik onder al die druk gaan knak.

Steyn se roman wen met die verloop van die verhaal die leser se empatie met die protagonis: daar is sterk, deurlopende innerlike dialoog en momente van broosheid en kwesbaarheid in die eensaamheid van sy huis, waar hy die moordsaak gereeld bepeins en besef: "as mens alleen bly, dink jy makliker aan donker dinge" (21). Herinneringe aan sy oorlede vrou en sy vervreemde seun spook by hom, maar word gebalanseer met teer oomblikke soos wanneer hy Emma se wilde janfrederik voer en later daarvan afskeid neem, asook die humoristiese tonele met Rommel, 'n hond wat op sy stoep vir hom gelos is. Steyn gebruik onder andere Mags se interaksie met diere om hom te lei na heelwording en die verwerking van sy trauma. Daar is ook ' $n$ tienermeisie se onskuldige toenadering wanneer sy in hom 'n veilige hawe teen die bose moordenaar vind; sy bak selfs pannekoek vir Mags om "vir 'n rukkie net veilig [te] voel" (194).

Steyn skryf met 'n meer psigologiese benadering as die meeste ander misdaadskrywers: Mags is nie ' $n$ alkoholis of 'n rokjagter nie, net 'n gebroke man wat deur middel van sy werk probeer keer dat sy eie wêreld in duie stort. Selfs wanneer Mags die bure se jong seun hardhandig hanteer-wat onder normale omstandighede geen regdenkende persoon se goedkeuring sal wegdra nie—smeek die leser byna saam met hom: "Kolonel. Moenie my werk vat nie" (152).

By die werk worstel hy met nog meer vrae: Word al die moorde deur dieselfde monster gepleeg? Is daar 'n na-aper? Hoeveel tyd het hulle oor voor nog 'n tienermeisie ontvoer word, voor nog 'n lyk gevind word? Met die opvolg van leidrade word die antagonis se forensiese beeld broksgewys duideliker. Die roman volg'n chronologies verloop; selfs datums en die dag van die week word aangedui, kompleet soos die C-gedeelte van 'n polisiedossier (186). Soveel kan in 'n kort tydjie gebeur en die leser baklei saam met die speurder teen die oorhand wat die horlosie het.

Al die leidrade, wat meestal dwaalspore is, help om die verhaal stelselmatig op die spits te dryf. Deur die boek hou Steyn die leser aan die raai; die roman handhaaf ' $n$ vinnige pas en boei deurgaans, sonder pretensie, met realistiese gebeure. Daar is 'n fyn balans tussen die bose en die goeie, dood en lewe asook wie die reg het om dáároor te mag besluit.

Alhoewel die roman binne die konvensies van die speurroman en misdaadverhaal bly, kom dit geensins resepmatig voor nie: die fyner nuanses in taal, die innerlike konflik van die protagonis en die afwisseling en soomlose oorgang tussen verlede en hede (byvoorbeeld die toneel op ble. 198-9) wys dat Steyn' $n$ fyn aanvoeling het vir die menslike psige, kousale handelinge, konteks en taal. Die verhaal het lae wat gestroop kan word en wat die leser wat die verhaal 'n tweede keer lees, beloon.

Nog 'n kwessie wat belig word, is die seksuele mishandeling van vroue en weliswaar nie net deur die moordenaar nie. 
So kom prostitusie ook ter sprake, sowel as 'n tienermeisie wat oor die internet 'n verhouding met 'n ouer man aanknoop omdat haar ma toegelaat het dat haar baas haar molesteer, 'n slagoffertjie wat weggeloop het omdat haar stiefpa haar gemolesteer het sonder dat ma haar wou glo, en 'n vrou wat toelaat dat haar man haar psigies, fisiek, seksueel en emosioneel aftakel omdat sy vir haar lewe vrees.

Steyn dwing nie sy siening op die leser af nie en gee ruimte aan die leser om self na te dink oor kwessies soos genadedood, die verwerking van verlies en die benarde posisie waarin die polisiemag hulle tans bevind. Hy betrek die leser aktief by die intrige deurdat hy ons met 'n paar onbeantwoorde vrae laat soos die kwessie van die vermiste DVD's en die skryf van die briewe.

Met die tydsaanduiding as 2014 en verwysings na spesifieke hofsake soos dié van Leigh Matthews en Inge Lotz, word die verhaal in ' $n$ resente milieu geplaas waarin die sterk mediadekking van dié hofsake nog vars in die leser se geheue is. Die eietydse plasing van die roman word versterk deur die konkrete plasing van gebeure in herkenbare voorstede in Kaapstad (soos Brackenfell, Bellville en Durbanville) en Menck se gedurige ligsinnige gespot met die gewilde CSI-televisieprogram (Crime Scene Investigation) se (onrealistiese) voorstelling van wat die taak van die polisie nou eintlik behels. Op dié manier hou Steyn die misdaad naby aan die leser-in tyd en plek-want moord en doodslag is vir ons alledaags: "'n Mens se lewe is die enigste ding wat goedkoper word in SuidAfrika" (318).
Die humor is skerp en is veral te vinde in die dialoog (veral Mags se onuitgesproke innerlike dialoog) tussen Mags en Menck. Dwarsdeur die roman beheers Steyn dialoog met gemak; dit is veral duidelik in Menck se dialoog, soos byvoorbeeld sy spitsvondige kommentaar in die ondervragingskamer (onder andere op ble. 55-61) en wanneer hy Mags se siel uittrek.

Wat die taal betref, wend Steyn meestal 'n staccato-styl aan om die protagonis se innerlike dialoog aan te dui, soos byvoorbeeld: "Linkerknie kort eintlik nuwe onderdele" (11) en "Gou badkamer toe" (21). Kragwoorde word sinvol en sonder oordaad deur die karakters gebruik; trouens soms wonder'n mens of van die karakters (soos polisiemanne en lede van'n rockgroep) nie méér behoort te vloek nie; dit maak egter die verhaal meer toeganklik vir die breër publiek en sodoende word die fokus nie op die taalgebruik geplaas nie. Steyn se beskrywing van die toneel deur die tienermeisie wat ontsnap het, is uiters knap gedaan (158-61).

Martin Steyn het met Donker spoor meer vermag as net' $n$ speurroman as blote (ont)spanningslektuur. Dit het' $n$ welverdiende ATKV-Woordveertjie in 2015 ontvang, sowel as tweede plek in Lapa se Lekkerlitkompetisie in 2014 (wat deur lesers sélf aangewys word). Met ' $n$ debuutroman soos dié, blyk dit dat Martin Steyn diep (donker) spore in die Afrikaanse speurroman gaan trap. Dit is daarom verblydend dat sy tweede roman, Skuldig, reeds die lig gesien het.

\footnotetext{
Nadine Hamman

Hamman@unisa.ac.za

Universiteit van Suid-Afrika, Pretoria
} 